The effects of learning style and gender consciousness on novices' learning from playing educational games

\title{
Li-Chun Wang
}

Graduate Institute of Information and Computer Education

National Taiwan Normal University, Taiwan

E-mail: cct101wang@gmail.com

\section{Ming-Puu Chen*}

Graduate Institute of Information and Computer Education

National Taiwan Normal University, Taiwan

E-mail: mpchen@ntnu.edu.tw

*Corresponding author

\begin{abstract}
This study investigated the effects of novices' learning style and gender consciousness on learning of programming concepts from game-based learning activities. Four classes of eighth graders with 59 males and 63 females participated in this study. Participants were identified as the diverger group and the converger group based on their stronger learning styles. Game-play activities were implemented to support participants' learning of programming concepts. The results revealed that (a) for the programming comprehension performance, the convergers outperformed the divergers; (b) participants' learning style and gender consciousness significantly affected their project performance; (c) for the high gender consciousness learners, the convergers performed better at abstract conceptualization and active experimentation than the divergers did; (d) for the divergers, the low gender consciousness learners possessed lower stereotype and were willing to challenge and performed better than the high gender consciousness learners; and (e) all the participants revealed positive intrinsic and extrinsic motivation.
\end{abstract}

Keywords: Learning style; Gender consciousness; Game-based learning; Computer programming

Biographical notes: Li-Chun Wang received her $\mathrm{Ph} . \mathrm{D}$. degree in Information and Computer Education from National Taiwan Normal University, Taiwan. Her research interests include learning motivation in ICT education and gamebased learning.

Ming-Puu Chen is Professor of the Graduate Institute of Information and Computer Education at National Taiwan Normal University, Taiwan. He received his Ph.D. degree with major achievement in Educational Technology from University of Northern Colorado, USA. His major research interests fall in the fields of personal epistemology in learning computers and digital gamebased learning. 


\section{Introduction}

In the digital era, junior high learners should acquire information fluency skills so that they could understand technology concepts and apply acquired knowledge to solve reallife problems (ISTE, 2007). Meanwhile, the programming skill has become the newly emerging literacy for the highly interactive digital world (Prensky, 2008). Learning to program requires learners to comprehend abstract concepts based on their previous experiences and transform the acquired concrete concepts into abstract mental conceptualizations; therefore, learners can apply the acquired programming knowledge and skills to solve real-world problems successfully (Soloway, 1993). However, the abstract attribution of programming concepts always causes difficulties in educational practice, especially for the novices (West \& Ross, 2002). In contrast with conventional teaching, game-based learning can play a role in helping novices to transform experience from concrete into abstract and facilitate learning motivation. Hence, how to design game-based learning activities to help learners to acquire programming skills needs to be investigated in the digital age.

\section{Theoretical backgrounds}

Although computer programming has been taught in elementary and junior schools for many years, there are gaps among individual learners in programming competency. The barriers for programming learning were knowledge itself since it is abstract (West \& Ross, 2002). Meanwhile, researchers suggested that game-based learning environment can work through a combination of challenge, engaging play, situated learning and problem-based learning and help learners construct knowledge (Adcock, 2008; Van Eck, 2007). Therefore, the present study examined the impact of game-based learning on learning of programming and explored the effects of individual differences on programming performance.

\subsection{Game-play and learning of programming}

There was considerable research regarding the application of games for learning. Although there has been much written about negative aspects of computer games, it has been recognized that computer games may cause positive impacts on learning (Inal \& Cagiltay, 2007; Kiili, 2005). For the negative aspects: (a) learners may gain less from learning when game features have been added to subject matters (Lepper \& Malone, 1987); and (b) games may not appeal to every student (Squire, 2003). These negative aspects imply that game features and specific domain knowledge should be taken into consideration when designing a game. For the positive aspect, the effects of game-based learning can be classified into three dimensions including cognition, skill and affection. From the cognition perspective, games play a role of cognitive tools to (a) provide multiple representations; (b) activate prior knowledge (Squire, 2003); (c) connect game experience and real-life learning experience (Pivec, 2007); and (d) provide trial-and-error opportunities for problem solving and help learners to engage in higher order cognitive thinking (Adcock, 2008). From the skill dimension, games play a role of trial-and-error practice to (a) improve learners' information literacy and skills (Druckman, 1995; de Freitas, 2006); and (b) provide rich learning experience for problem solving and transference skills (Connolly, Stansfield, \& Hainey, 2007). From the affective perspective, games play a role in motivating learners by adding challenge, feedback, curiosity and fantasy features (Garris, Ahlers, \& Driskell, 2002; Lepper \& Malone, 1987). Although the application of games for learning may bring many promising advantages as described 
above, there are few studies provided empirical evidence supporting the effectiveness of game-based learning.

In the educational practice of learning computers, introductory programming learning emphasizes the syntax and semantics while overlooking the transference of abstract concepts that were implicit in programming running (Mayer, 1992). Kolb (1984) argued that knowledge was constructed through the transformation of experience during experiential learning. Correspondingly, the critical factor of concept learning was the transference of the learning experience that games provided (Gros, 2007). The context of a game can produce a simplification of reality that embedded learning strategies to support knowledge construction, clarification and consolidation. Hence, game-play can be employed as a cognitive tool for enhancing knowledge construction. When engaging in game play, learners can construct knowledge by trial and error and consolidate and elaborate the acquired knowledge through progressive challenges. Learners are highly engaged and motivated in computer games, which provided a rich learning experience and played an important role in facilitating the formation of skills, motivation and attitudes (Inal \& Cagiltay, 2007). Therefore, integrating game-play within learning of programming might motivate learners to play the game intrinsically and enrich their learning experiences.

\subsection{Individual differences and learning}

Individual differences, such as learning styles, gender and other personal background factors could have impacts on skills, aptitudes and learning preferences with the application of technology in educational practices. Keefe (1987) defined learning style as "characteristic cognitive, affective, and physiological behaviors that serve as relatively stable indicators of how learners perceive, interact with, and respond to the learning environment." It refers to the mental processes and instructional settings a learner applied as learning strategies to perform specific tasks (More, 1993). As shown in Fig. 1, Kolb (1984) classified learning styles into diverging, assimilating, converging and accommodating according to the differences of transferring experiences into meaningful knowledge. The divergers are best at viewing concrete situations with multiple viewpoints; the assimilators are best at organizing information with a clear logical format; the convergers are best at finding practical uses for ideas and theories; and the accommodators are attracted to new challenges and experiences (Kolb, 1984). Identifying learners' stronger learning styles help educators understand what learners' informationprocessing habits are and how they perceive, think, remember, and solve problems (Messick, 1984). Previous studies concluded that matching learners' learning style with instructional style enhanced learners' performance and suggested that it may be difficult for learners to change their learning styles, whereas learning strategies can be adopted by learners and changed through teaching (Ford \& Chen, 2001; Pintrich \& Johnson, 1990; Wang \& Chen, 2008).

The concept of gender consciousness represented gender role, gender traits and gender equality. Gender consciousness can be thought of as a continuum along which generalized gender awareness is succeeded by a consciousness of the rights associated with specific gender locations within a given system (Gerson \& Peiss, 1985). Gender consciousness may be affected by personal background, parents, learning experiences and social culture. Furthermore, researchers suggested that gender consciousness may play a facilitating role in educational contexts (Herring \& Marken, 2008). In computer science, gender consciousness is especially related to the gender stereotype, which was deepened in conventional education. In the digital era, it is necessary to redefine conventional 
gender stereotypes and debunk taboos connected with gender positions and abilities. Therefore, it is worthwhile to investigate the effects of novices' gender consciousness and learning style on learning of programming concepts from game-based learning activities.

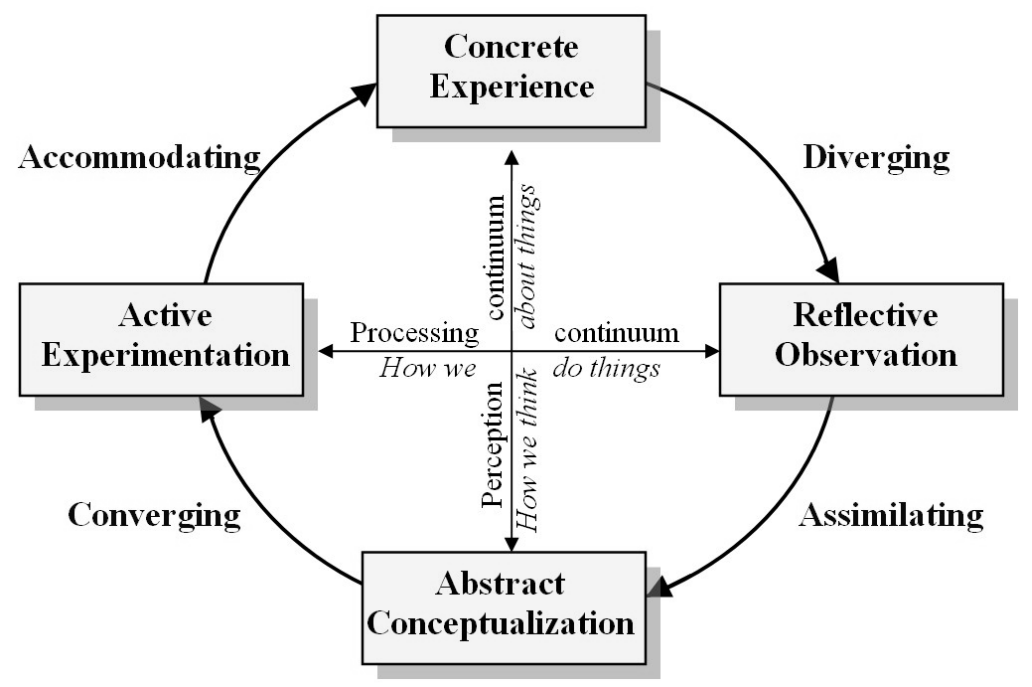

Fig. 1. Kolb identified 4 types of learners based on information-processing and information perception preferences

\section{Research methods}

In the present study, game-play activities were employed to motivate and facilitate novice learners to learn programming concepts through drill and practice. The effects of participants' learning style and gender consciousness on comprehension of programming concepts, project performance and motivation were examined. The participants, research design, the pedagogical framework of game play, and research instruments are described as follows.

\subsection{Participants}

Four classes of eighth graders, with 59 males and 63 females, participated in the gamebased learning project. All of them were novice in programming language, and had nineweek basic training on Flash multimedia authoring experience prior to the experiment. Game-play activities were employed to facilitate learners to learn Flash Actionscript. Finally, an animation project was employed that required learners to apply their Flash Actionscript programming knowledge acquired from the previous game-play activities.

\subsection{Research design}

The major purpose of the present study was to examine the effects of learning style and gender consciousness on comprehension of programming concepts, project performance and motivation. The dependent variables included comprehension performance on programming concepts, project production performance and motivation. The independent variables were learning style (the divergers vs. the convergers) and gender consciousness 
(high gender-consciousness vs. low gender-consciousness). The effective sample sizes for the diverger group and the converger group are 41 and 33, and for the high genderconsciousness group and the low gender-consciousness group are 39 and 35, respectively. The experimental instruction was conducted in a 1-hour-per-week technology course and lasted for six weeks. A game-play activity was implemented to fulfill Kolb's experiential learning cycle and facilitate participants' transformation of learning experiences in computer programming during the experiment. In the beginning of the experiment, all groups received a 10-minute general introduction to the experiment and followed by a 30-mintue introduction to programming concepts using Flash Actionscript. Then, a threephases (three hours) computer-based game-play activity was conducted for participants to acquire programming concepts from game-pay activity. Finally, a 2-hour programming project was conducted for learners to apply acquired programming knowledge to achieve the given tasks. The convergers and the low gender-consciousness learners were expected to outperform their counterparts in both the comprehension and project performance due to their advantages of individual characteristics. Furthermore, all participants were expected to reveal the same level of high motivation toward learning since all of them learned programming concepts from game-play.

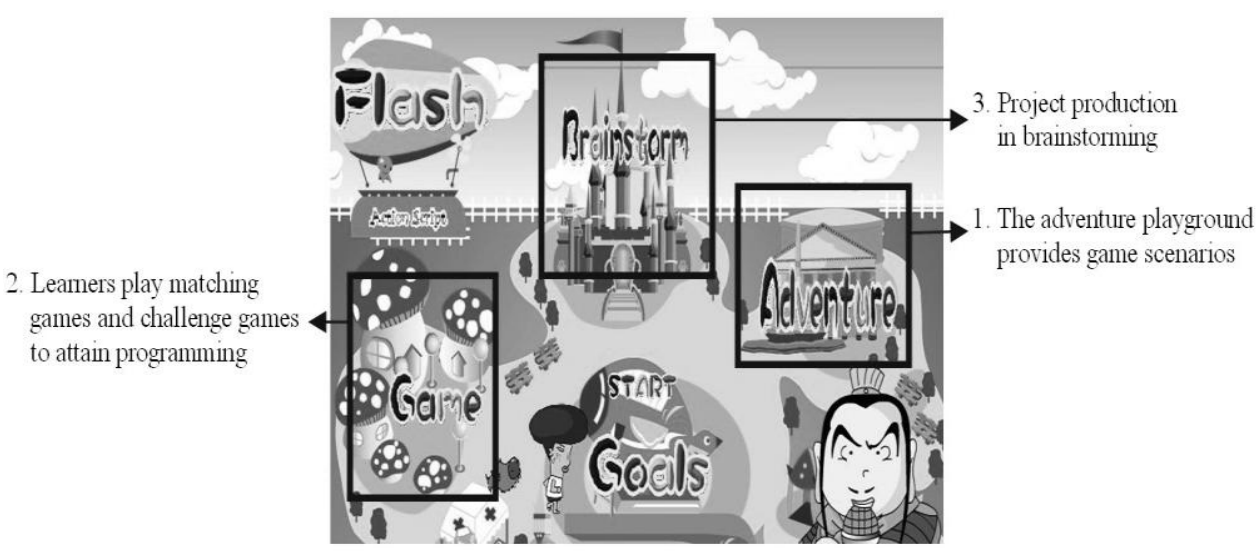

Fig. 2. The framework of the game-based learning context for this study

\subsection{The pedagogical framework of game-play}

As shown in Fig. 2, the pedagogical framework consists of three parts: the adventure playground, the game (game-play) and the brainstorming. The adventure playground provided game scenarios for learning programming concepts. When learners made ambiguous answers, the system would provide hints to promote understanding; whereas when learners made the correct answers, the system would provide positive feedback to enhance learning motivation. In the game-play phase, learners construct programming concepts from interactive game-play. Learner played matching-games and challengegames to learn the embedded declarative knowledge and procedural knowledge. The main purpose of matching game was to provide trial-and-error practice on identifying programming concepts. Similarly, challenging-games were employed to clarify and consolidate well-constructed concepts by progressive challenges. With help of the learning by experiencing in the challenging-games, learners could rehearse and recognize declarative knowledge and elaborate mental models of programming concepts. Finally, in the brainstorming phase, programming knowledge and skill were related to the production of the programming project. The programming project was employed to 
promote conceptual learning from game-play and apply acquired knowledge to solve real-life problems.

This study incorporated game-play within the learning of programming concepts using Flash Actionscript. The pedagogy, types of knowledge and attribution of technology were integrated together into the game design in order to enhance learners' conceptual learning and problem-solving skills. From the concept attainment perspective, the way to embed learning strategies in game-based learning for facilitating concept construction, knowledge absorption, conceptual attainment and gaming strategies are sequenced as followed (as shown in Table 1).

Table 1

Types of knowledge to be learned, process of conceptual attainment and gaming strategies employed during game-play

\begin{tabular}{|c|l|l|l|}
\hline $\begin{array}{c}\text { Type of } \\
\text { knowledge }\end{array}$ & \multicolumn{1}{|c|}{$\begin{array}{c}\text { Process of concept } \\
\text { attainment }\end{array}$} & Gaming strategies & Game-play \\
\hline $\begin{array}{c}\text { Declarative } \\
\text { knowledge }\end{array}$ & $\begin{array}{l}\text { Concept construction from } \\
\text { concrete experiences }\end{array}$ & $\begin{array}{l}\text { Learning by playing } \\
\text { Interactive scenario } \\
\text { Trial and error } \\
\text { Hint } \\
\text { Feedback }\end{array}$ & $\begin{array}{l}\text { Adventure } \\
\text { playground }\end{array}$ \\
\hline $\begin{array}{l}\text { Procedural } \\
\text { knowledge }\end{array}$ & $\begin{array}{l}\text { Concept consolidation } \\
\text { from reflective observation }\end{array}$ & $\begin{array}{l}\text { Learning by } \\
\text { challenging } \\
\text { Progressive challenge } \\
\text { Matching game } \\
\text { Progress record }\end{array}$ & Game play \\
\hline $\begin{array}{c}\text { Conditional } \\
\text { knowledge }\end{array}$ & $\begin{array}{l}\text { Concept transfer from } \\
\text { abstract conceptualization } \\
\text { and active experimentation }\end{array}$ & $\begin{array}{l}\text { Learning by } \\
\text { designing } \\
\text { Hint/Guide } \\
\text { Programming project }\end{array}$ & Brainstorming \\
\hline
\end{tabular}

- Concept construction from concrete experience: According to the needs in an effective process of knowledge construction, a learning game should include interactive scenarios, multiple representations, trial-and-error practices, hints and appropriate feedbacks (Gros 2007; Kiili, 2005; Prensky, 2001; Van Eck, 2007). As learners engage in game-play, they play and learn by identifying concepts, classifying concepts, assimilating new knowledge and eliciting motivation. Interactive scenarios provided concrete experiences and elicited learners' learning motivation. Multiple representations could address learners' diverse learning preferences and facilitate new knowledge assimilation. Trial-and-error practices, hints and appropriate feedbacks help learners to clarify ambiguous concepts. The knowledge constructed during this phase will serve as a base for next stage of concept construction.

- Concept consolidation from reflective observation: The employed gaming strategies during this phase should contain matching-games, progressive challenge levels and progress records (Sweetser \& Wyeth, 2005). Matching-games promote learners to identify examples from non-examples. Csikszentmihalyi (1997) emphasized the balance between an individual's skill and difficulty of a task. With progressive challenge levels, learners play the game by trial and error, assimilating, mastering and challenging to maintain motivation (Sweetser \& Wyeth, 2005; Inal 
\& Cagiltay, 2007). Progress records facilitate learners to reflect on any reuse of their playing strategies, to elaborate on the established knowledge, and to be motivated. During this phase, learners transform the acquired concrete experiences into abstract conceptualization by reflection. The learners become more active to challenge the game.

- Concept transfer from abstract conceptualization to active experimentation: Games provide opportunities for connecting virtual life with real life (Inal \& Cagiltay, 2007). The transformation of learning experience that game provided is a critical factor for concept learning (Gros, 2007). In this phase, learners play the role of designers. They learned by designing and completing the programming project. According to the experiential learning cycle, abstract conceptualization leads to active experimentation. Well-constructed knowledge serves as a foundation for successful project production since the production is transferred from and based on learners' acquired abstract concepts. The attribution of knowledge during this phase belongs to conditional knowledge that learners must know how and why to do so.

\subsection{Research instruments}

The research instruments employed in the present study include learning style scale, gender consciousness scale, online programming post-test, and project production scale. The research instruments are described as follows.

The learning style scale was developed by Kolb (1984) and consisted of 12 statements. Each statement had four items (A, B, C, D). The learners were asked to rate each item from 4 to 1 corresponding to how well the statements describe them (4 indicated the best fit, 3 indicated some fit, 2 indicated seldom fit and 1 the least fit). The sums of item A, B, C and D were the scores of concrete experience $(\mathrm{CE})$, reflective observation (RO), abstract conceptualization (AC) and active experimentation (AE), respectively. The difference between $\mathrm{AC}$ and $\mathrm{CE}$ represented the higher preference of concrete experience or concrete experience, whereas the difference between AE and RO represented active experimentation or reflective observation. The top 45 percent and last 45 percent represented the stronger and weaker of concrete experience or reflective observation and the same for abstract conceptualization or active experimentation. Thus, in this study, participants were identified as the divergers (41) and the convergers (33) from the perspective of the above learning styles. The perceive perspective was used to describe how learners transform experience through concrete experience or abstract conceptualization, whereas the process perspective was used to describe how learners complete a task through reflective observation or active experimentation. For divergers, individuals preferred watching and feeling, meaning that individuals transform experiences by concrete experiences and complete the task by reflective observations. For convergers, individuals preferred thinking and doing, meaning that individuals transform experiences by abstract conceptualization and complete the task by active experimentation. Therefore, owning to the abstract attribution of programming concepts, the present study intended to investigate whether the convergers outperform the divergers while learning from game-based learning activities.

Gender consciousness scale was conducted to investigate the perception toward the public and private gender consciousness of technology learning in conventional social culture. The scale was revised from Snell and Johnson (2004) and consisted of 30 items. Higher scores represent greater public gender consciousness and private gender consciousness. Public gender consciousness represents the tendency of being aware of 
other reactions to aspects of one own particular gender. In contrast, private gender consciousness involves the tendency of being personally aware of gender-related phenomena about oneself and society. It also represented a more conventional attitude toward gender stereotype, gender role and gender traits. The overall reliability coefficient of the gender consciousness scale was .96 (Cronbach's alpha).

Online programming posttest was developed to investigate learners' programming comprehension. The test consisted of 14 items and was conducted immediately after the programming project in the sixth week. The overall reliability coefficient of the programming comprehension test was .78 (Cronbach's alpha).

Project production scale consisted of eight items and was conducted to investigate learners' programming capability. During the fifth to sixth week, learners were asked to finish the project about the convert of temperature from degree Fahrenheit to degree Celsius. The assessment items included the variable naming, variable type, expressions, and Flash actionscript. Each item scored from 0 to 3 (0: unfinished, 1: partial correct, 2: exactly correct, 3: apply to new content) and with a total scale of 24-point. The overall reliability coefficient of the project production was .87 (Cronbach's alpha).

The motivation questionnaire was conducted at the end of the fifth week with the aim to investigate the intrinsic and extrinsic motivation after game-play. The questionnaire was revised from Weinstein (1990) and consisted of six statements which are divided into intrinsic and extrinsic subscales. Learners were asked to rate themselves on a 5-point Likert-type scale with response options from 1 (strongly disagree) to 5 (strongly agree). The reliability coefficient of the motivation questionnaire was .79 (Cronbach's alpha).

\section{Data analysis and results}

Multivariate analyses of variance (MANOVA) were performed to investigate the effects of learning style and gender consciousness on participants' programming performance and motivation in game-based learning. The significance level was set to .05 for the study.

The mean scores of the learning style groups and the gender consciousness groups on comprehension and project performance are shown in Table 2. The converger group scored higher than the diverger group and the low gender-consciousness group scored higher than the high gender-consciousness group both in comprehension and project performance.

Before conducting MANOVAs, homogeneity test of variance between subjects was examined. Box's test showed that the homogeneity of variance between subjects was not significant (Box's M=11.45, $F=1.205, p=.286$ ). Therefore, the variances across groups were equal and MANOVAs should be further conducted. The Wilks' lambda showed that the interaction of learning style and gender consciousness was significant on project performance (Wilks' Lambda $=.837, F_{(2,69)}=6.711, p=.002$, partial $\eta 2=.163$ ). The main effect of learning styles (Wilks' Lambda $=.793, F_{(2,69)}=9.005, p<.001$, partial $\eta 2=.207$ ) and gender consciousness (Wilks' Lambda $=.892, F_{(2,69)}=4.188, p=.019$, partial $\eta 2=.108)$ were significant.

The MANOVA summary on comprehension and project performance is shown as Table 3. The two-way interaction of learning style and gender consciousness on comprehension performance was not significant $\left(F_{(1,70)}=.334, p=.565\right.$, partial $\left.\eta 2=.005\right)$, but the two-way interaction on project performance was significant $\left(F_{(1,70)}=12.887\right.$, $p=.001$, partial $\eta 2=.155$ ). Therefore, the main effects of the independent measures on 
comprehension performance were examined and the simple main effects on the project performance were further analyzed. For comprehension performance, the main effect of learning style was significant $\left(F_{(1,70)}=7.219, p=.009\right.$, partial $\left.\eta 2=.093\right)$, meanwhile, the main effect of gender consciousness was not significant $\left(F_{(1,70)}=3.383, p=.070\right.$, partial $\eta 2=.046)$. As the group means shown in Table 2 , the converger group $(M=9.33)$ outperformed the diverger group $(\mathrm{M}=7.93)$ on comprehension performance. Although the low gender-consciousness group ( $M=9.00)$ scored slightly higher than the high genderconsciousness group $(\mathrm{M}=8.06)$ but did not reach the significant level. In other words, the convergers comprehend the abstract programming concepts better than the divergers, and the low gender-consciousness learners and the high gender-consciousness learners comprehend the abstract programming concepts equally.

Table 2

Group means of the learning style groups and the gender consciousness groups on comprehension and project performance

\begin{tabular}{|c|c|c|c|c|c|}
\hline $\begin{array}{l}\text { Dependent } \\
\text { Measure }\end{array}$ & Source & Aspects & Mean & $\begin{array}{c}\text { Std. } \\
\text { Deviation }\end{array}$ & $\mathrm{N}$ \\
\hline \multirow{4}{*}{ Comprehension } & \multirow{2}{*}{ Learning style } & Diverger & 7.93 & 2.23 & 41 \\
\hline & & Converger & 9.33 & 2.12 & 33 \\
\hline & \multirow{2}{*}{$\begin{array}{c}\text { Gender } \\
\text { consciousness }\end{array}$} & Low & 9.00 & 2.24 & 39 \\
\hline & & High & 8.06 & 2.25 & 35 \\
\hline & Total & & 8.55 & 2.18 & 74 \\
\hline \multirow{5}{*}{$\begin{array}{c}\text { Project } \\
\text { performance }\end{array}$} & \multirow{2}{*}{ Learning style } & Diverger & 18.44 & 2.92 & 41 \\
\hline & & Converger & 20.36 & 2.43 & 33 \\
\hline & \multirow{2}{*}{$\begin{array}{c}\text { Gender } \\
\text { consciousness }\end{array}$} & Low & 20.08 & 2.12 & 39 \\
\hline & & High & 18.43 & 3.34 & 35 \\
\hline & Total & & 19.30 & 2.70 & 74 \\
\hline
\end{tabular}

For project performance, the group means are shown as Table 4. The summary of the simple main effects for the learning style groups is shown as Table 5. For the diverger group, the simple main effect of gender-consciousness was significant $\left(F_{(1,40)}=20.559\right.$, $p<.001)$, and for the converger group, however, the simple main effect of gender consciousness was not significant $\left(F_{(1,32)}=.627, p=.435\right)$. As the group means shown in Table 4 , for the divergers, the low gender-consciousness group $(M=20.10)$ outperformed the high gender-consciousness group $(\mathrm{M}=16.70)$ on project performance, but for the covergers, both gender-consciousness groups performed equally. Similarly, for the high gender-consciousness group, the simple main effect of learning style was significant $\left(F_{(1,34)}=19.242, p<.001\right)$, and for the low gender-consciousness group, however, the simple main effect of learning style was not significant $\left(F_{(1,38)}=.003, p=.954\right)$. As the group means shown in Table 4, for the high gender-consciousness learners, the covergers $(M=20.73)$ outperformed the divergers $(M=16.70)$ on project performance, but for the low gender-consciousness learners, the covergers and the divergers performed equally.

The group means on intrinsic and extrinsic motivation are shown as Table 6. Participants showed positive attitudes toward learning motivation. As for participants' intrinsic and extrinsic motivation, the low gender-consciousness group (intrinsic $\mathrm{M}=3.43$, extrinsic $\mathrm{M}=3.40$ ) scored slightly higher than the high gender consciousness group (intrinsic $M=3.13$, extrinsic $M=3.30)$. On the other hand, the divergers $(M=3.30)$ scored 
slightly higher on intrinsic motivation than the convergers $(M=3.27)$, while the convergers $(\mathrm{M}=3.44)$ scored slightly higher on extrinsic motivation than the divergers $(\mathrm{M}=3.28)$.

Table 3

MANOVA summary of learning style and gender consciousness on comprehension and project performance

\begin{tabular}{|c|c|r|c|c|c|c|}
\hline \multirow{2}{*}{ Source } & $\begin{array}{c}\text { Dependent } \\
\text { Variable }\end{array}$ & $\begin{array}{c}\text { Type III } \\
\text { Sum of } \\
\text { Squares }\end{array}$ & df & $\begin{array}{c}\text { Mean } \\
\text { Square }\end{array}$ & F & Sig \\
\hline \multirow{2}{*}{ Learning style } & Comprehension & 33.591 & 1 & 33.591 & $7.219 *$ & .009 \\
\cline { 2 - 7 } Gender consciousness & Project & 72.549 & 1 & 72.549 & $12.390^{*}$ & .001 \\
\cline { 2 - 7 } & Comprehension & 15.742 & 1 & 15.742 & 3.383 & .070 \\
\hline \multirow{2}{*}{$\begin{array}{c}\text { Learning style } \times \text { Gender } \\
\text { consciousness }\end{array}$} & Comprehension & 33.591 & 1 & 33.591 & $5.737 *$ & .019 \\
\cline { 2 - 7 } Error & Project & 75.461 & 1 & 75.461 & $12.887 *$ & .001 \\
\hline & Comprehension & 325.721 & 70 & 4.653 & & \\
\cline { 2 - 7 } & Project & 409.887 & 70 & 5.856 & & \\
\hline
\end{tabular}

Table 4

Group means on project performance by learning style and gender consciousness

\begin{tabular}{|c|c|c|c|c|}
\hline \multirow{2}{*}{ Learning style } & $\begin{array}{c}\text { Gender } \\
\text { consciousness }\end{array}$ & M & SD & N \\
\hline \multirow{2}{*}{ Diverger } & High & 16.70 & 2.83 & 20 \\
\cline { 2 - 5 } & Low & 20.10 & 1.90 & 21 \\
\hline \multirow{2}{*}{ Converger } & High & 20.73 & 2.49 & 15 \\
\cline { 2 - 5 } & Low & 20.06 & 2.41 & 18 \\
\hline
\end{tabular}

Table 5

Summary of the simple main effects on project performance

\begin{tabular}{|c|l|r|r|r|r|c|}
\hline \multicolumn{1}{|c|}{ Group } & \multicolumn{1}{|c|}{ Source } & $\begin{array}{c}\text { Type III } \\
\text { Sum of } \\
\text { Squares }\end{array}$ & df & $\begin{array}{c}\text { Mean } \\
\text { Square }\end{array}$ & F & Sig \\
\hline Diverger & Gender consciousness & 118.088 & 1 & 118.088 & $20.559 *$ & .000 \\
\hline Converger & Gender consciousness & 3.759 & 1 & 3.750 & .627 & .435 \\
\hline $\begin{array}{c}\text { High Gender } \\
\text { consciousness }\end{array}$ & Learning style & 139.438 & 1 & 139.438 & $19.242 *$ & .000 \\
\hline $\begin{array}{c}\text { Low Gender } \\
\text { consciousness }\end{array}$ & Learning style & .015 & 1 & .015 & .003 & .954 \\
\hline
\end{tabular}

Before conducting the MANOVAs, homogeneity test of variance between subjects was examined. Box's test showed that the homogeneity of variance between 
subjects was not significant (Box's $\mathrm{M}=14.361, F=1.511, p=.137$ ). Therefore, the variances across groups were equal and the difference of participants' motivation between groups was further examined. The MANOVA summary of learning style and gender consciousness on intrinsic and extrinsic motivation is shown as Table 7. All of the two-way interactions were not significant. The main effects of learning styles $\left(F_{(1,69)}\right.$ $=.575, p=.566$, partial $\eta 2=.016)$ and gender consciousness $\left(F_{(1,69)}=1.218, p=.302\right.$, partial $\eta 2=.034)$ on intrinsic and extrinsic motivation were not significant. The results indicated that no matter which learning style participants possessed, they revealed similar positive intrinsic and extrinsic motivation. Similarly, in spite of their high or low gender consciousness, participants revealed similar positive intrinsic and extrinsic motivation.

\section{Table 6}

Mean scores of learning style and gender consciousness on intrinsic and extrinsic motivation

\begin{tabular}{|c|c|c|c|c|c|}
\hline $\begin{array}{l}\text { Dependent } \\
\text { Measure }\end{array}$ & Source & Aspects & Mean & $\begin{array}{c}\text { Std. } \\
\text { Deviation }\end{array}$ & $\mathrm{N}$ \\
\hline \multirow{4}{*}{$\begin{array}{l}\text { Intrinsic } \\
\text { motivation }\end{array}$} & \multirow{2}{*}{ Learning style } & Diverger & 3.302 & .767 & 41 \\
\hline & & Converger & 3.272 & 1.089 & 33 \\
\hline & \multirow{2}{*}{ Gender consciousness } & Low & 3.428 & .831 & 39 \\
\hline & & High & 3.133 & .994 & 35 \\
\hline \multirow{5}{*}{$\begin{array}{l}\text { Extrinsic } \\
\text { motivation }\end{array}$} & \multirow{2}{*}{ Learning style } & Diverger & 3.285 & .717 & 41 \\
\hline & & Converger & 3.445 & .981 & 33 \\
\hline & \multirow{2}{*}{ Gender consciousness } & Low & 3.402 & .810 & 39 \\
\hline & & High & 3.305 & .887 & 35 \\
\hline & & Total & 3.356 & .843 & 74 \\
\hline
\end{tabular}

Table 7

MANOVA summary of learning styles and gender consciousness on intrinsic and extrinsic motivation

\begin{tabular}{|l|l|r|r|r|r|r|}
\hline \multirow{2}{*}{ Source of Variation } & Aspects & $\begin{array}{c}\text { Type III } \\
\text { Sum of } \\
\text { Squares }\end{array}$ & $\mathrm{df}$ & $\begin{array}{c}\text { Mean } \\
\text { Square }\end{array}$ & \multicolumn{1}{c|}{$\mathrm{F}$} & Sig \\
\hline \multirow{2}{*}{ Learning style } & Intrinsic & .059 & 1 & .059 & .071 & .790 \\
\cline { 2 - 7 } & Extrinsic & .478 & 1 & .478 & .654 & .421 \\
\hline \multirow{2}{*}{ Gender consciousness } & Intrinsic & 1.966 & 1 & 1.966 & 2.362 & .129 \\
\cline { 2 - 7 } & Extrinsic & .122 & 1 & .122 & .167 & .684 \\
\hline \multirow{2}{*}{$\begin{array}{l}\text { Learning style } \times \text { Gender } \\
\text { consciousness }\end{array}$} & Intrinsic & 1.574 & 1 & 1.574 & 1.892 & .173 \\
\cline { 2 - 7 } Error & Extrinsic & .125 & 1 & .125 & .171 & .681 \\
\cline { 2 - 7 } & Intrinsic & 58.264 & 70 & .832 & & \\
\cline { 2 - 7 }
\end{tabular}




\section{Discussions and conclusions}

This study presents empirical evidence on learning from educational games from the perspectives of individual difference. Three findings are concluded and discussed as follows.

(1) Learners with various gender consciousnesses performed similarly when learning from educational game-play

The results of the present study indicated that learners with various gender consciousnesses performed similarly on comprehension of programming concepts when learning from educational game-play. This may be inferred that they were all motivated and maintained at high levels of motivation by the challenging game-play. On the other hand, by integrating game-based learning activities, participants' knowledge construction and consolidation were enhanced and the effects of negative gender consciousness were diminished. Just as suggested by Prensky (2001), strategy games could promote judgment and knowledge process, and sports game or role-play game could promote learners to elaborate acquired knowledge through continuous practice and feedback. Since only challenge games was employed in this study, whether other types of games, such as roleplaying games, strategy games, etc., work similarly needs to be further studied.

(2) The convergers are skillful in transferring concrete experiences into abstract conceptualizations and outperformed the divergers when learning from educational game-play

As suggested by the experiential learning perspective, divergers preferred concrete experience and reflective observation, whereas convergers preferred abstract conceptualization and active experimentation (Kolb, 1984). Therefore, in this study, it was hypothesized that the divergers could construct abstract conceptualizations and active experimentation successfully with the help of the given experiential game-based context and performed equally as the convergers did. However, the results have rejected this hypothesis and implied that the compensation effect was not occurred. According to the experiential learning perspective, concrete experiences lead to observations and reflections. Observations and reflections are assimilated and transformed into abstract conceptualizations on a basis of active experimentation. The convergers assimilated concrete experiences and transformed them into abstract conceptualizations with the help of their learning preference advantage in abstract knowledge. In contrast, although gameplay activities provided the divergers with concrete experiences of programming concepts, they might have comprehended the abstract knowledge through the supported reflective observations but their transformation of concrete experiences into abstract conceptualizations was not as efficient as the convergers. In other words, the enhancement effect has revealed in the convergers. Therefore, it is suggested to provide more supportive reflections and scaffolds in the gaming context to facilitate the divergers' abstract conceptualization process.

(3) High gender consciousness hindered the divergers' problem-solving performance but not the convergers

In this study, project production was conducted to investigate how well learners apply constructed knowledge to solve real-life problems. The findings indicated that learning style interacted with gender consciousness to affect participants' project performance. The higher gender consciousness means that the learners possessed the higher conventional technology stereotype. For the convergers, due to the advantages in abstract conceptualization and active experimentation, the high-gender-consciousness convergers performed as well as the low-gender-consciousness convergers in applying the acquired 
knowledge to project production. Similarly, the high-gender-consciousness convergers also outperformed the high-gender-consciousness divergers, who possessed higher conventional technology stereotype. Furthermore, although the divergers were not good in assimilating abstract conceptualizations, those divergers with low gender consciousness were willing to challenge and, therefore, performed better than those divergers with high gender consciousness. As suggested by previous studies (Gros, 2007; Prensky, 2001; Van Eck, 2007), games included problem solving would spark creativity and games assisted learners in developing skills on analytical and problem-solving. In other words, providing role models, hand-on experiences, multiple modes of representations, self-awareness of the knowledge construction process and problemsolving strategies would help the high-gender-consciousness divergers to debunk conventional technology stereotype and compensate for their disadvantaged learning style (Van Eck, 2007; Gros, 2007). Therefore, it is suggested to provide multiple perspective supports to facilitate creative thinking and debunk conventional technology stereotype for the high-gender-consciousness divergers. In addition, the findings also suggested that with the help of game-based learning participants could maintain high levels of learning motivation regardless of individual preferences in learning style and gender consciousness.

\section{Implications}

The implications and suggestions for future works are stated as follows. First, due to the abstract attribution of programming knowledge and the traits of learning styles, this study only divided the participants into the diverger group and the converger group. Since assimilators and accommodators were not investigated in the present study, it is suggested that the effects of the four learning styles with gender consciousness on learning could be further examined. Second, gender consciousness was developed continuously and could be affected by personal background, parents, learning experience and social culture. Collaborative game-based learning may be helpful in diminishing the negative effects of gender consciousness. Therefore, it is suggested to be further examined. Third, literature revealed that games had positive impacts on learning (Inal \& Cagiltay, 2007; Kiili, 2005), but the results from the empirical studies toward game-based learning remained inconclusive. It is suggested that the type of knowledge and attribution of technology should be considerately designed when employing game strategies for learning. Finally, just as Van Eck's (2007) asserted, games can assist learners in developing analytical and problem-solving skills and transferring skills. In the present study, however, only declarative knowledge and procedural knowledge were examined. Therefore, it is suggested that the higher-order programming knowledge (e.g. conditional knowledge) should be further implemented and investigated in the game-based learning environment.

\section{Acknowledgements}

This study was sponsored by the National Science Council of Taiwan, under the Grants NSC 98-2511-S-003-034-MY3 and NSC 99-2511-S-003-027-MY3. 


\section{References}

Adcock, A. (2008). Making digital game-based learning working: An instructional designer's perspective. Library Media Connection, 26(5), 56-57.

Connolly, T. M., Stansfield, M., \& Hainey, T. (2007). An application of games-based learning within software engineering. British Journal of Educational Technology, 38(3), 416-428.

Csikszentmihalyi, M. (1997). Finding flow: The psychology of engagement with everyday life. New York: Basic Books.

de Freitas, S. (2006). Learning in immersive worlds: A review of game-based learning. JISC (Joint informational Systems Committee) report (2006), Retrieved from http://www.jisc.ac.uk/eli_outcomes.html.

Druckman, D. (1995). The educational effectiveness of interactive games. In D. Crookall $\&$ K. Arai (Eds.), Simulation and Gaming across Disciplines and Cultures. CA: Sage.

Ford, N., \& Chen, S. (2001). Matching/mismatching revisited: An empirical study of learning and teaching styles. British Journal of Educational Teaching, 32(1), 5-22.

Garris, R., Ahlers, R., \& Driskell, J. E. (2002). Games, motivation and learning: A research and practice model. Simulation \& Gaming, 33(4), 441-467.

Gerson, J. M., \& Peiss, K. (1985). Boundaries, negotiation, consciousness: Reconceptualizing gender relations. Social Problems, 32, 317-331.

Gros, B. (2007). Digital games in education: The design of game-based learning environment. Journal of Research on Technology in Education, 40(1), 23-38.

Herring, S. C., \& Marken, J. A. (2008). Implications of gender consciousness for students in information technology. Women's Studies, 37(3), 229-256.

Inal, Y., \& Cagiltay, K. (2007). Flow experiences of children in an interactive social game environment. British Journal of Educational Technology, 38(3), 454-464.

International Society for Technology in Education (ISTE). (2007). National educational technology standards for students. Retrieved from http://cnets.iste.org/students/pdf/NETS_for_Students_2007.pdf.

Keefe, J. W. (1987). Learning style theory and practice. Reston, VA: National Association of Secondary School Principals.

Kiili, K. (2005). Content creation challenges and flow experience in educational games: The IT-Empreor case. Internet and Higher Education, 8, 183-198.

Kolb, D. A. (1984). Experimental learning. Englewood Cliffs NJ: Prentice-Hall.

Lepper, M. R., \& Malone, T. W. (1987). Intrinsic motivation and instructional effectiveness in computer-based education. In R. E. Snow \& M. J. Farr (Eds.), Aptitude, Learning, and Instruction: Vol. 3. Conative and Affective Process Analyses (pp. 255-286). NJ: Lawrence Erlbaum.

Mayer, R. E. (1992). Teaching for transfer of problem-solving skills to computer programming. In E. D. Corte, M. C. Linn, H. Mandl, \& L. Verschaffel (Eds.), Learning Environment and Problem Solving (pp. 193-206). NY: Springer-Verlag.

Messick, S. (1984). The nature of cognitive styles: Problems and promises in educational research. Educational Psychologist, 19, 59-74.

More, A. J. (1993). Learning styles and the classroom. British Columbia University, Vancouver. (ERIC Document Reproduction Service No. ED368479)

Pintrich, P. R., \& Johnson, G. R. (1990). Assessing and improving students' learning strategies. New Directions for Teaching and Learning, 42, 83-92.

Pivec, M. (2007). Play and learn: Potentials of game-based learning. British Journal of Educational Technology, 38(3), 387-393.

Prensky, M. (2001). Digital game-based learning. New York: McGraw-Hill.

Prensky, M. (2008). Programming: The new literacy. Edutopia Magazine. Retrieved from http://www.edutopia.org/programming. 
Snell, W. E., Jr., \& Johnson, G. (2004). Development and validation of the multidimensional gender consciousness questionnaire: A measure of gender awareness. Retrieved from http://www4.semo.edu/snell/scales/MGCQ.htm.

Soloway, E. (1993). Should we teach students to program? Communications of the ACM, $36(10), 21-24$.

Squire, K. (2003). Video games in education. International Journal of Intelligent Games \& Simulation, 2(1), 49-62.

Sweetser, P., \& Wyeth, P. (2005). GameFlow: A model for evaluating player enjoyment in games. Computer in Entertainment, 3(3), 1-24.

Van Eck, R. (2007). Six ideas in search of a discipline. In B. E. Shelton \& D. A. Wiley (Eds.), The Design and Use of Simulation Computer Games in Education (pp.31-56). Rotterdam: Sense Publishers.

Wang, L. C., \& Chen, M. P. (2008). Enhancing ICT learning by matching type of instruction and individual differences. In K. McFerrin et al. (Eds.), Proceedings of Society for Information Technology \& Teacher Education International Conference 2008 (pp. 2272-2278). Chesapeake, VA: AACE.

Weinstein, C. E. (1990). Learning and study strategies inventory high school version (LASSI-HS): User's manual. Clearwater, FL: H \& H. Retrieved from http://www.hhpublishing.com/_assessments/LASSI/LASSI-HS_Manual.pdf.

West, M., \& Ross, S. (2002). Retaining females in computer science: A new look at a persistent problem. JCSC, 17(5), 1-7. 